\title{
PERLINDUNGAN HUKUM TERHADAP KONSUMEN DALAM MELAKUKAN TRANSAKSI E-COMMERCE DITINJAU DARI UNDANG-UNDANG PERLINDUNGAN KONSUMEN UNDANG-UNDANG NOMOR 8 TAHUN 1999 (Studi Kasus Kerudungbyramana Bandung)
}

\author{
Herlina Basri \\ Fakultas Hukum Universitas Pamulang \\ dosen01956@unpam.ac.id
}

\begin{abstract}
In the current era of the digital economy, the use of internet media as a means of electronic commerce (e-commerce) has experienced a significant and very rapid development. The existence of e-commerce regulations in Indonesia has not been comprehensive in terms of providing legal protection for e-commerce actors. The issues raised in this study are about the aspects of legal arrangements for implementers and users of e-commerce in Indonesia and about e-commerce arrangements that are expected to be applied in Indonesia. The method of approach used is normative juridical or doctrinal legal research, where this legal research emphasizes the study of legal documents and library materials relating to the main issues of law. The strategy in marketing the veil export by using e-commerce is part of e-business, where the scope of e-business is broader, not only for business but also includes the collaboration of business partners, negotiations, customer service, job vacancies, etc. . ecommerce is used not only as an ordinary online marketing media but also as a means to interact and attract buyers to make it easier to conduct national trade transactions.
\end{abstract}

Keywords; e-commerce, Transactions

\begin{abstract}
ABSTRAK
Pada era ekonomi digital saat ini, penggunaan media internet sebagai sarana perdagangan secara elektronik (e-commerce) mengalami perkembangan yang signifikan dan sangat pesat. Keberadaan regulasi e-commerce di Indonesia belum secara komprehensif dalam hal memberikan perlindungan hukum terhadap para pelaku e-commerce. Permasalahan yang diangkat dalam penelitian ini yaitu tentang aspek pengaturan hukum bagi pelaksana dan pengguna $e$-commerce di Indonesia dan tentang pengaturan $e$-commerce yang diharapkan dapat diterapkan di Indonesia. Metode pendekatan yang digunakan adalah yuridis normatif atau penelitian hukum doktrinal, dimana penelitian hukum ini menekankan pada penelaahan dokumen-dokumen hukum dan bahan-bahan pustaka yang berkaitan dengan pokok-pokok permasalahan hukum. Strategi dalam hal pemasaran ekspor kerudung dengan menggunakan ecommerce ini merupakan bagian dari e-business, di mana cakupan e-business lebih luas, tidak hanya sekedar perniagaan tetapi mencakup juga pengkolaborasian mitra bisnis, negoisasi, pelayanan nasabah, lowongan pekerjaan dan lain-lain. e-commerce digunakan bukan hanya sebagai media pemasaran online biasa tetapi juga sebagai sarana untuk berinteraksi dan menarik para buyer agar lebih mudah dalam melakukan transaksi perdagangan nasional.
\end{abstract}

Kata Kunci: e-commerce, Transaksi 


\section{PENDAHULUAN}

Electronic Commerce atau dikenal dengan istilah e-commerce adalah kegiatankegiatan bisnis yang menyangkut konsumen, manufaktur, service provider, dan pedagang perantara dengan menggunakan jaringanjaringan internet dan komputer. Dilihat berdasarkan bagaimana produk dikomunikasikan kepada konsumen, maka perdagangan dibagi menjadi dua cara, yaitu yang pertama secara on line dan kedua secara off line. Yang dimaskud dengan perdagangan secara off line di dalam penelitian ini adalah perdagangan yang mana dilakukan secara konvensional, yaitu dimana penjual dan pembeli bertemu secara langsung dan melakukan transaksi face to face, atau melalui perantara perdangangan, dalam hal ini tidak menggunakan sarana internet.

Pembangunan hukum di Indonesia diharapkan dapat menciptakan kepastian investasi terkait dengan penegakan dan perlindungan hukum bagi investor yang akan melakukan investasi di Indonesia. Perdagangan adalah salah satu bagian dari bidang perekonomian yang diharapkan dapat memperoleh perlindungan hukum.

Adapun perdagangan secara on line adalah perdagangan yang dilakukan dengan menggunakan sarana internet. Itulah yang kemudian dikenal dimasyarakat sebagai istilah e-commerce. Setidaknya terdapat tujuh jenis dasar e-commerce saat ini, yaitu :

(1) Business-to-Business (B2B), (2) Businessto-Consumer (B2C), (3) Consumer-toConsumer (C2C), (4)Consumer-to-Business (C2B), (5) Business-to-Administration (B2A), (6) Consumer-to-Administration ( $\mathrm{C} 2 \mathrm{~A})$, dan (7) Online-to-Offline (O2O). Secara khusus di dalam penelitian ini akan dibahas kegiatan $e$ commerce yang dilakukan dengan cara Consumer-to-Consumer (C2C).

Pada dasarnya " $\mathrm{C} 2 \mathrm{C}$ merupakan jenis e-commerce yang meliputi semua transaksi elektronik barang atau jasa antar konsumen. Umumnya transaksi ini dilakukan melalui pihak ketiga yang menyediakan platform online untuk melakukan transaksi tersebut" Contoh aplikasi yang dipakai saat ini di
Indonesia melalui website Tokopedia, Bukalapak, Shopee, Lazada dan Blibli dimana dalam hal memasarkan produknya si penjual dapat secara langsung berjualan produknya melalui website-website tersebut. Seperti . Tokopedia, Bukalapak, Shopee, Lazada dan Blibli.

Kegiatan e-commerce yang bersifat masif saat ini banyak dilakukan melalui sosial media seperti facebook salah satunya disebabkan karena pengguna sosial media di Indonesia jumlahnya sangat banyak. Saat ini saja perkirakan 150 juta penduduk Indonesia adalah pengguna media sosial. Bandingkan dengan jumlah penduduk Indonesia pada tahun 2019 yang diperkirakan berjumlah 266,91 juta jiwa, dimana jumlah penduduk usia produktif kelompok umur 15-64 tahun mencapai 183,36 juta jiwa $(68,7 \%$ dari total populasi). Dengan demikian pengguna sosial media di Indonesia sekitar $82 \%$ dari total jumlah penduduk usia produktif. $81 \%$ pengguna sosmed di Indonesia menggunakan sosial media facebook, dan 80\% menggunakan sosial media Instagram. "Indonesia sendiri menduduki perkingkat ketiga sebagai negara dengan pengguna

sekaligus target audiens iklan pengguna Facebook terbesar di dunia, dengan jumlah 130 juta pengguna yang aktif bulanan

\section{METODE PENELITIAN}

Metode yang digunakan dalam penelitian ini adalah metode penelitian yuridis empiris dengan menganalisis permasalahan dilakukan dengan cara memadukan bahan-bahan hukum (yang merupakan data sekunder dengan data primer) yang diperoleh di lapangan yaitu tentang pelaksanaan transaksi e-commerce ini

Metode yuridis normative pendekatan yang dilakukan berdasarkan bahan hukum utama dengan cara menelaah teori-teori, asasasas hukum serta peraturan perundangundangan yang berhubungan dengan penelitian ini. Penelitian ini merupakan penelitian kualitatif dan deskriptif 


\section{PERMASALAHAN}

Adapun perumusan masalah dalam penelitian ini adalah apakah perdagangan melalui e-commerce yang diaplikasikan menggunakan sosial media dapat memberikan perlindungan hukum bagi konsumennya, apakah perdagangan dengan cara e-commerse dapat memberikan manfaat buat konsumen. Apakah pemasaran Kerudungbyramana melalui transaksi ecommerce memberikan peluang yang besar bagi Produsen-produsen lainnya?

\section{PEMBAHASAN}

\section{Tinjauan Umum Tentang Transaksi E-Commerce}

Pengertian

transaksi

$e-$

commerce secara umum yaitu suatu transaksi jual beli atas suatu produk barang, jasa atau informasi antarmitra bisnis dengan memakai jaringan computer yang berbasiskan kepada internet. Berdasarkan pasal 1 ayat (17) rancangan undang-undang tentang pemanfaatan teknologi informasi, "kontrak elektronik adalah perjanjian yang dimuat dalam dokumen elektronik yang dituangkan dengan kontrak elektronik mengikat dan memiliki kekuatan hukum sebagai suatu perikatan". Dari pengertian diatas, dapat disimpulkan bahwa perjanjian secara elektronik adalah kesepakatan antara kedua belah pihak yang dilakukan secara elektronik, dimana para pihak dalam melaksanakan perjanjian tidak memerlukan tatap muka secara langsung.

Persoalan transaksi e-commerce sangatlah berkaitan dengan perjanjian hal ini berkenaan dengan banyak digunakannya perjanjian baku didunia bisnis,maka sudah sepatutnya kita menetukan perjanjian apakah yang baku untuk hukum perjanjiaan dalam transaksi e-commerce. Biasanya dalam mengenai pencamtuman klausula eksonerasi (Exoneratie Clause).
Dalam transaksi bisnis dengan memakai akta perjanjian baku, sangat terbuka kemungkinan bagi pihak pelaku usaha untuk melakukan pembatasan atau penghapusan tanggungjawab. Dalam arti, bahwa pelaku usaha dapat menentukan sendiri ketentuan-ketentuan tentang pengalihan tanggungjawab dan/atau resiko, dari pihak pelaku usaha (exonerant) kepada pihak adherent, dalam sebagian dari beberapa syarat baku yang ditetapkan sepihak itu. Syarat semacam itu dalam hukum disebut dengan istilah exoneratie clause (syarat eksonerasi), yaitu syarat dalam suatu perjanjian di mana satu pihak membebaskan diri dari tanggungjawab yang dibebankan kepadanya oleh regelend recht (Fockema Andreae, 1983: 129).

Klausula eksonerasi adalah syarat yang secara khusus membebaskan pengusaha dari tanggungjawab terhadap akibatyang merugikan yang timbul dari pelaksanaan perjanjian. Klausula eksonerasi dapat berasal dari rumusan pengusaha secara sepihak dapat juga berasal dari rumusan undang-undang.

Klausula eksonerasi berpeluang menimbulkan penindasan yang satu dengan yang lainnya. Maka pekasanaan perjanjian yang ada Klausula eksonerasi harus dilaksanakan dengan itikad baik. Pada dasarnya klausula eksonerasi dalam suatu perjanjian adalah hal yang boleh. Eksonerasi terhadap kerugian yang timbul karena kesengajaan pengusaha adalah bertentangan dengan kesusilaan. Dalam hal ini pengadilan dapat mengesampingkan klausula eksonerasi ini. Isi perjanjian bukanlah harga mati karena pada pasal 1339 penjelasan 1338 ayat (3) tentang itikad baik.

Menurut Abdulkadir Muhammad, klausala eksenorasi mempunyai tujuan utama yaitu mencegah pihak konsumen merugikan pihak pengusaha karena dalam hubungan ekonomi dikatakan bahwa pembeli adalah raja, sebagai raja konsumen dapat berbuat semaunya 
sehingga merugikan pengusaha. Pengusaha mencoba menghindari kemungkinan timbulnya kerugian dengan menciptakan syarat baku yang disebut eksonerasi (Muhammad, 1992 : 20).

E-commerce juga merupakan dampak dari perkembangan teknologi adapun beberapa cara transaksi dalam e-commerce yaitu:

1. Pertama melalui penawaran jual beli dan penerimaan jual beli secara online, contohnya: melalui website situs di internet atau posting di mailing list dan newsgroup dan bisa juga menggunakan undangan untuk para customer melalui model business to business.

2. Kedua melalui transaksi dengan menggunakan email, dalam hal ini baik penjual maupun pembli harus memliki email address masing-masing agar mempermudah proses pembelian barang atau jasa serta dalam menentukan cara pembayaran yang ingin digunakan para pihak (Komputer, 2001 : 63).

3. Ketiga melalui transaksi chatting atau video conference yaitu dengan cara menawarkan sesuatu menggunakan model dialog interaksi melalui internet, seperti melalui handphone, video converence semuanya melalui elektronik,mereka dapat bertatap muka langsung gambar dan mendengar suara antara penjual dan pembeli.

4. Keempat melalui transaksi web atau cara merchant yang menyediakan katalog barang yang dilengkapi deskripsi produk yang dijual oleh sang penjual produk.istilahnya disebut dengan order form dan shopping cart.

\section{Transaksi Jual Beli/Belanja Online Menurut Undang-Undang Perlindungan Konsumen}

Dengan pendekatan Undang-Undang Perlindungan Konsumen, dapat kita tarik kesimpulan bahwa salah satu pelanggaran terhadap hak konsumen, pasal $4 \mathrm{UU}$ Perlindungan Konsumen menyebutkan bahwa hak-hak konsumen.

Dan selaku konsumen sesuai Pasal 4 huruf $h$ Undang-Undang Perlindungan Konsumen tersebut berhak mendapatkan kompensasi, ganti rugi dan/atau penggantian apabila barang dan/atau jasa yang diterima tidak sesuai dengan perjanjian atau tidak sebagaimana mestinya. Sedangkan, pelaku usaha itu sendiri sesuai Pasal 7 huruf $g$ Undang-Undang Perlindungan Konsumen berkewajiban memberi kompensasi, ganti rugi dan/atau penggantian apabila barang dan/atau jasa yang diterima atau dimanfaatkan tidak sesuai dengan perjanjian.

Apabila pelaku usaha melanggar larangan memperdagangkan barang/jasa yang tidak sesuai dengan janji yang dinyatakan dalam label, etiket, keterangan, iklan atau promosi penjualan barang dan/atau jasa tersebut, maka pelaku usaha dapat dipidana berdasarkan Pasal 62 ayat (1) Undang-Undang Perlindungan Konsumen yang berbunyi:

"Pelaku usaha yang melanggar ketentuan sebagaimana dimaksud dalam Pasal 8, Pasal 9, Pasal 10, Pasal 13 ayat (2), Pasal 15, Pasal 17 ayat (1) huruf a, huruf b, huruf c, huruf e, ayat (2) dan Pasal 18 dipidana dengan pidana penjara paling lama 5 (lima) tahun atau pidana denda paling banyak Rp 2 miliar”.

\section{Kontrak Elektronik dan Perlindungan Konsumen Menurut Undang-Undang ITE dan PP PSTE}

Transaksi jual beli Online, meskipun dilakukan secara online, berdasarkan UndangUndang ITE dan PP PSTE tetap diakui sebagai transaksi elektronik yang dapat dipertanggungjawabkan. Persetujuan dalam membeli barang secara online dengan cara melakukan klik persetujuan atas transaksi merupakan bentuk tindakan penerimaan yang menyatakan persetujuan dalam kesepakatan pada transaksi elektronik. Tindakan penerimaan tersebut biasanya didahului pernyataan persetujuan atas syarat dan ketentuan jual beli secara online yang dapat dikatakan juga sebagai salah satu bentuk 
Kontrak Elektronik.

Kontrak Elektronik menurut Pasal 47 ayat (2) PP PSTE dianggap sah apabila ${ }^{1}$ :

a. terdapat kesepakatan para pihak;

b. dilakukan oleh subjek hukum yang cakap atau yang berwenang mewakili sesuai dengan ketentuan peraturan perundangundangan;

c. terdapat hal tertentu; dan

d. objek transaksi tidak boleh bertentangan dengan peraturan perundang-undangan, kesusilaan, dan ketertiban umum.

Kontrak Elektronik itu sendiri setidaknya harus memuat hal-hal sebagai berikut:

a. data identitas para pihak

b. objek dan spesifikasi

c. persyaratan transaksi elektronik

d. harga dan biaya

e. prosedur dalam hal terdapat pembatalan oleh para pihak

f. ketentuan yang memberikan hak kepada pihak yang dirugikan untuk dapat mengembalikan barang dan/atau meminta penggantian produk jika terdapat cacat tersembunyi dan

g. pilihan hukum penyelesaian Transaksi Elektronik.

Dengan demikian, pada transaksi elektronik di lakukan, disini kita dapat menggunakan instrumen Undang-Undang ITE dan/atau PP PSTE sebagai dasar hukum dalam menyelesaikan permasalahan kalau terjadi sengketa permasalahn dalam jual beli online.

Terkait dengan perlindungan konsumen, Pasal 49 ayat (1) PP PSTE menegaskan bahwa Pelaku Usaha yang menawarkan produk melalui Sistem Elektronik wajib menyediakan informasi yang lengkap dan benar berkaitan dengan syarat kontrak, produsen, dan produk yang ditawarkan. Lebih lanjut ditegaskan lagi bahwa Pelaku Usaha wajib memberikan

\footnotetext{
${ }^{1}$ Peraturan Pemerintah Nomor 82
}

Tahun 2012 tentang Penyelenggaraan Sistem dan Transaksi Elektronik (PP PSTE). PP PSTE telah diperbarui menjadi Peraturan Pemerintah Nomor 71 Tahun 2019, Pasal 47 ayat (2) kejelasan informasi tentang penawaran "kontrak" atau "iklan". ${ }^{2}$

\section{Jika Barang yang Anda Terima Tidak Sesuai dengan yang Diperjanjikan}

Pasal 49 ayat (3) PP PSTE mengatur khusus tentang hal tersebut, yakni Pelaku Usaha wajib memberikan batas waktu kepada konsumen untuk mengembalikan barang yang dikirim apabila tidak sesuai dengan perjanjian atau terdapat cacat tersembunyi.

Menurut Prof. R. Subekti, S.H. dalam bukunya tentang "Hukum Perjanjian", wanprestasi adalah kelalaian atau kealpaan yang dapat berupa 4 macam kondisi yaitu:

a. Tidak melakukan apa yang disanggupi akan dilakukannya;

b. Melaksanakan apa yang dijanjikannya, tetapi tidak sebagaimana dijanjikan;

c. Melakukan apa yang dijanjikannya tetapi terlambat;

d. Melakukan sesuatu yang menurut perjanjian tidak boleh dilakukannya.

Menurut Moegni Dojodirjo, dalam pasal 1365 KUHPerdata mengatur pertanggungjawaban yang diakibatkan oleh perbuatan melawan hukum baik karena berbuat (positif=culpa in committendo) atau karena tidak berbuat (culpa in ommittendo). Sedangkan pasal 1366 mengatur tentang pertanggung-jawaban yang diakibatkan oleh kesalahan karena kelalaian (onrechtmatige natalen). 3

\section{Pidana Penipuan dalam Transaksi Jual Beli Online}

Dalam hal pelaku usaha atau penjual Online ternyata menggunakan identitas palsu atau melakukan tipu muslihat dalam jual beli online tersebut, maka pelaku usaha tsb dapat juga dipidana berdasarkan Pasal 378 Kitab

\footnotetext{
${ }^{2}$ Peraturan Pemerintah Nomor 82 Tahun 2012 tentang Penyelenggaraan Sistem dan Transaksi Elektronik (PP PSTE). PP PSTE telah diperbarui menjadi Peraturan Pemerintah Nomor 71 Tahun 2019, Pasal 49 ayat (1)

3 Moegni Dojodirjo, "Perbuatan Melawan Hukum - Cet II ", Pradnya Paramitha, Jakarta, 1982. hal. 27
} 
Undang-Undang Hukum Pidana (KUHP) tentang penipuan dan Pasal 28 ayat (1) UU ITE tentang menyebarkan berita bohong dan menyesatkan yang mengakibatkan kerugian konsumen dalam Transaksi Elektronik. 4

\section{Perlindungan Terhadap Konsumen Dalam Transaksi e-commerce (Study kasus Kerudungbyramana Bandung)}

Sistem keamanan dalam dunia computer mulai menjadi perhatian serius para peneliti dan praktisi teknologi informasi sejak ditemukanya teknologi jaringan computer. Pemicu berkembangnya isu dibidang ini adalah karena adanya fenomena pengiriman data melalui media tranmisi (darat, laut dan udara) yang mudah "dicuri" oleh mereka yang tidak berhak. Data mentah dari sebuah computer yang dikirim ke computer lain pada dasarnya rawan terhadap "intervensi" pihak ketiga, sehingga diperlukan suatu strategi khusus agar terjadi, paling tidak ada dua hal: (Indrajit, 2001: 83)

1. Data yang dikirimkan tidak secara "fisik" diambil oleh pihak lain yang tidak berhak; atau

2. Data yang dikirimkan dapat "diambil secara fisik", namun yang bersangkutan tidak dapat membacanya.

Information cecurity yang dapat diterima di dalam e-commerce mutlak dibutuhkan. Di era internet, semua kebutuhan dan keinginan sedapat mungkin diterima dengan cepat, mudah dan aman. Untuk itulah peranan teknologi keamanan informasi benerbener dibutuhkan (Wahyudi O. W., 2001 : 17). Sistem keamanan informasi memiliki empat macam tujuan yang sangat mendasar, yaitu:

1. Confidentiality

Menjamin apakah informasi yang

4 Undang-Undang Nomor 11 Tahun 2008 tentang Informasi dan Transaksi Elekronik sebagaimana telah diubah oleh Undang-Undang Nomor 19 Tahun 2016, Pasal 28 ayat (1) dikirim tersebut tidak dapat dibuka atau tidak sapat diketahui oleh orang lain yang tidak berhak. Terutama untuk data yang teramat penting, dibutuhkan tingkat kerahasiaan yang sangat tinggi, yang hanya bisa diakses oleh orangorang tertentu saja (orang-orang yang berhak) yang memiliki sangkutan atau hubungan dalam hal atau urusan akses tersebut,demi suatu bentuk nyata dalam ilmu kerahasian yang terbentuk dalam akses sistem tersebut.

\section{Integrity}

Menjamin konsistensi dan keutuhan data sesuai dengan aslinya, sehingga upaya orang-orang yang tidak bertanggungjawab untuk melakukan penduplikatan dan perusakan data bisa dihindari.

\section{Availability}

Menjamin pengguna yang sah agar bisa mengakses informasi dan sumber miliknya sendiri. Tujuanya adalah untuk memastikan bahwa orang-orang yang memang berhak tidak ditolak untuk mengakses informasi yang memang menjadi haknya.

\section{Legitimate use}

Menjamin kepastian bahwa sumber tidak digunakan (informasi tidak diakses) oleh orang-orang yang tidak bertanggung jawab (orang-orang yang tidak berhak).

Pada saat ini banyak metode yang dapat dipakai untuk pembayaran transaksi $e$ commerce. Dalam transaksi e-commerce pembayaran dilakukan secara sedikit berbeda, biasanya dalam transaksi ini pembayaran lazimnya dilakukan secara elektronik. Pembayaran dengan kartu kredit/kartu debit dimana dalam dunia kartu kredit/kartu debit ada beberapa pihak yang berperan dalam transaksi e-commerce. Pemegang kartu kredit/kartu debit disebut dengan istilah cardholder. Kartu kredit/kartu debit diterbitkan oleh sebuah bank, yang biasa disebut issuer. Bank-bank tersebut melakukan licensee merek kartu kredit/kartu debit dari institusi kartu kredit/kartu debit seperti Visa, Mastercard 
atau Maestro. Selanjutnya pedagang (merchant) yang dapat menerima kartu kredit/kartu debit juga memiliki hubungan dengan sebuah bank, yang dikenal dengan istilah acquirer. Pada acquirer inilah merchant memiliki account yang akan "menampung" uang dari cardholder.

1. Pembayaran dengan $e$-Check

E-Check atau electronic check merupakan salah satu metode pembayaran dalam transaksi ecommerce. Dalam pembayaran dengan $e$-Check, pertama tama konsumen membuka account bank di internet untuk pertama kali. Kemudian konsumen mengeluarkan e-check miliknya untuk membayar. Penerima $e$ check ini mengirimkan cek tersebut ke bank untuk konfirmasi bahwa transaksi tersebut bener-bener valid, akhirnya bank memindahkan uang dari rekening pengirim ke rekening penerima cek sesuai dengan nilai yang tercantum.

2. Pembayaran dengan Digital Cash

Digital cash memiliki karakteristik utama, yaitu transnationality of digital cash, dimana digital cash memilki kemampuan mengalir secara bebas melewati batas hukum Negara lain. Karakteristik inilah yang menjadi sumber kelebihan dan kekurangan digital cash. Di satu sisi, digital cash menjadi lebih efisien, tidak berbelitbelit, di sisi lain hal ini dapat menimbulkan pertentangan antara prinsip kebebasan cyberspace dengan hukum suatu Negara (Wahyudi O. W., Mengenal e-Commerce

, 2001:25-126).

Dalam melakukan transaksi online selama ini Kerudungbyramana menerima dan melakukan transaksi dengan cara konsumen membayar dengan cara transfer rekening yang dikelompokkan dengan pembayaran no 1 yaitu dengan pembayaran dengan kartu debit/kredit. Yang dalam hal ini tidak ada mengalami kendala. Barang akan dikirim setelah konsumen mentransfer sejumlah nominal yang telah disepakati didalam katalog belanjaan. Setelah itu pihak kerudungbyramana akan mengirimkan barang pesanan konsumen dengan segera 1 sampai 3 hari diluar kota, kalau dalam kota bisa waktu 1 hari.

Sepanjang transaksi yang dilakukan

oleh Kerudungbyramana dimana penulis wawancara CEOnya bernama Nadifa Amalia Gunadi Putri, S.E., M.Ak, tidak ada terjadi wanprestasi atau perbuatan melawan hukum dimana sesuai dengan yang disepakati konsumen tidak ada merasakan dan mengalami kekecewaan. Dalam hal ini penulis juga membuktikan dengan mengunjungi situs atau toko onlinenya di IG dan Shopee dengan melihat dan membaca komentkoment dari konsumen di situs IG dan Shopee tersebut yang dapat di lihat di link Kerudungbyramana tersebut yaitu IG: https://instagram.com/kerudungramana ?igshid=g1doopo46qev

\section{Dan Shopee :}

https://shopee.co.id/ndfagunadi?v $=675 \&$ $s m t t=0.0 .3$

Dan dari penelurusan penulis tidak ada menemukan kekecewaan dari konsumen yang rata-rata berbelanja para kaum hawa yang senang berbusana Muslimah.

\section{Pengaturan hukum dalam melakukan transaksi e-commerce}

Hukum di Indonesia belum memiliki pengaturan yang jelas mengenai transaksi e-commerce, maka dari itu penulis merujuk pada pengaturan perjanjian jual beli secara konvensional yang ada dalam KUH perdata untuk menghaji transaksi e-commerce. Menurut Mieke Komar Kantaatmadja perjanjian jual beli yang dilakukan melalui media elektronik internet tidak lain adalah merupakan perluasan dari konseo perjanjian jual beli yang ada dalam KUH Perdata. Perjanjian jual beli melalui internet ini memiliki dasar hukum 
perdagangan konvensional atau jual beli dalam hukum perdata. Perbedaanya adalah bahwa perjanjian melalui internet ini bersifat khusus karena terdapat unsur peranan yang sangat dominan dari media dan alat-alat elektronik.

Menurut pasal $1457 \quad \mathrm{KUH}$ Perdata jual-beli adalah suatu persetujuan dengan mana pihak yang satu mengikatkan dirinya untuk menyerahkan suatu barang, dan pihak yang lain untuk membayar harga yang dijanjikan. Unsur-unsur pokok (essentiallia) perjanjian jual beli adalah barang dan harga. Sesuai dengan asas Konsensualisme yang menjiwai perjanjian dalam KUH Perdata, perjanjian jaul beli itu sudah dilahirkan pada detik tercapainya "sepakat" mengenai barang dan harga. Begitu kedua belah pihak setuju dengan barang dan harga, maka lahirlah perjanjian jual beli yang sah. Sifat konsensual dari jual beli menurut Pasal 1458 berbunyi "Jual beli dianggap sudah terjadi antara kedua belah pihak seketika setelah mereka mencapai sepakat tentang barang dan harga, meskipun barang itu belum diserahkan maupun harganya belum dibayar". Jadi dapat disimpulkan bahwa dengan disebutkannya kata "sepakat" saja tanpa harus membuat suatu tulisan, akta dan lain sebagainya, maka suatu perjanjian telah lahir secara sah atau mengikat para pihak yang membuatnya dan berlaku sebagai Undang - undang bagi mereka yang membuatnya.

\section{PENUTUP}

\section{Kesimpulan}

Bentuk perlindungan hukum terhadap konsumen dalam transaksi $e$ commerce telah disesuaikan dengan undang-undang perlindungan konsumen Nomor 8 Tahun $1999 \quad$ (Tentang Perlindungan Konsumen) Serta diterapkan sesuai peraturan yang diatur dalam proses transaksi e-commerce tersebut, yang mana telah diatur dalam beberapa pasal dan perundang-undangan yang terdapat pada Undang - undang Nomor 11 Tahun 2008 tentang Informasi dan Transaksi Elektronik dan Undangundang Perdagangan Undang-Undang No 7 Tahun 2014

Ketiga undang-undang tersebut dapat mengatur adanya berbagai bentuk transaksitransaksi e-commerce antara pihak penjual dan pembeli atau pelaku usaha dan konsumen, berdasarkan perjanjianperjanjian tertentu yang sesuai peraturan perundang-undangan tersebut.

Masalah - masalah yang dihadapi dalam transaksi e-commerce yaitu adanya suatu konflik dalam hubungan antara konsumen akhir dengan pelaku usaha yang belum maksimal menyajikan fasilitas dalam transaksi online atau bisnis e-commerce, hal ini diawali tidak adanya kepercayaan berupa jenis perjanjian yang digunakan dalam transaksi e-commerce ini. Dalam transaksi e-commerce ini hanya menggunakan transaksi dalam perjanjian dengan semua fasilitas digital termasuk tanda tangan, namun masaalah tersebut dapat diatasi dengan adanya penguat bentuk-bentuk transaksi online yaitu dengan diaturnya segala urusan mulai dari perlindungan konsumen yang semuanya termasuk dalam Undang-undang perlindungan konsumen Nomor 8 Tahun 1999 dan bentuk-bentuk fasilitas online yang dikuatkan dengan kekuatan hukum sebagai bukti-buktinya, salah satunya adanya perjanjian jual beli secara online yang dilindungi oleh undang-undang informasi dan transaksi elektronik, karena semuanya telah mencukup kebutuhan dalam bertransaksi online, maka masalahmasalah yang terjadi dalam bisnis $e$ commerce dapat diatasi dengan baik dan benar guna membantu menghindari permasalahan hukum yang dihadapi dikemudian hari baik masalah yang timbul berdasarkan kesengajaan pelaku bisnis 
ataupun konsumen.

\section{Saran}

Untuk dapat lebih memberi kepastian hukum dalam transaksi e-commerce sebaiknya selalu diterangkan dengan jelas dalam bentuk transaksi online baik barang maupun jasa tentang klausula yang mengatur tentang perlindungan konsumen dan memberitahukan batasanbatasan untuk konsumen sebagai pembeli barang atau pengguna jasa online tentang kejelasan status hukum jual beli yang dilakukan dalam bentuk apapun baik dalam status hukum sebagai penjual atau pelaku bisnis tersebut atau kita sebagai konsumen itu sendiri agar tercapai suatu sistem bentuk kepastian hukum yang merata adil dan makmur sesuai falsafah dalam undang-undang dan ideology pancasila yang berlaku sebagai acuan hukum di Negara kita. Dalam hal ini pemerintah seharausnya dapat membeikan perlindungan hukum dibatas "konsumen akhir" yang menurut undangundang tersebut ataupun "konsumen antara" sesuai peraturan perundangundangan yang ada sekalipun sudah melalui batas wilayah Indonesia atau Negara karena sudah pasti untuk bicara bisnis e-commerce maka merupakan bisnis yang mengglobal diseluruh dunia dan sudah seharusnya pemerintah memberikan dukungan atas kemajuan zaman pada masa ini dimana segalanya hampir mengunakan fasilitas online atau yang serba online ini dengan memperkuat tatanan hukum perundang-undangan yang mengatur transaksi online tersebut.

Baik pihak konsumen atau pun pelaku usaha yang baik berupa pelaku usaha berupa jasa maupun barang - barang hal ini agar dapat lebih memberikan rasa nyaman pada keduanya yaitu pelaku usaha tersebut maupun konsumen tersebut karena pada dasarnya masyarakat berkeinginan untuk memajukan juga kesejahteraan masyarakat salah satunya dengan mengaplikasikan layanan serba online dengan majunya pola piker masyarakat dalam berbisnis maka merupakan babak awal proses kemajuan zaman yang sangat pesat mulai dari sekarang hingga dimasa yang akan dating.

Agar para pebisnis bisa menjaga kepercayaan konsumen seperti Kerudungbyramana lakukan, agar transaksi online bisa membudaya apalagi dalam masa pandemi covid saat ini sangat menguntungkan dengan dirumah saja efisien waktu dan biaya dan hasil memuaskan. Semoga apa yang dilakukan oleh CEO Kerudungbyramana bisa menginspirasi banyak orang terutama pebisnis muda yang kebanyakan para milineal atau siapa saja yang tertarik dengan bisnis online ini.

\section{DAFTAR PUSTAKA}

Abdul Kadir Muhammad, Hukum Perikatan, (Bandung, Citra Aditya Bakti, 1992).

Berinovasi.com, Perkembangan E-Commerce $d i$ Indonesia, http://berinovasi.com/2017/12/11/per kembangan-e-commerce-diindonesia/, diunduh hari Minggu tanggal 23 Juni 2019.

Deny Kurnia, Hukum Perjanjian I, Standar Kontrak, http://www.academia.edu/7287203/H ukum_perjanjian_1._Standar_kontrak _Pengertian, diunduh hari Minggu tanggal 23 Juni 2019.

Elis Herlina dan Sri Santi, Model Perjanjian Baku Pada Kontrak Berlangganan Sambungan Telekomunikasi Telepon Selular Pasca Bayar, Jurnal Hukum IUS QUIA IUSTUM NO. 3 VOL. 23 JULI 2016: 415 - 438.

\section{https://instagram.com/kerudungra} mana?igshid=g1doopo46qev

Hukum Online.com, Kedudukan Istri Dalam Melakuka Perbuatan Hukum, https://www.hukumonline.com/klinik /detail/lt51466c18c9a9f/kedudukanistri-dalam-melakukanperbuatanhukum/, diunduh hari Minggu tanggal 23 Juni 2019. 
Johannes Gunawan. Penggunaan Perjanjian Standar dan Implikaslnya pada Asas Kebebasan Berkontrak. Dalam Projustitia No. 3 Tahun V Edisi Oktober 1987.

Katadata.co.id, Jumlah Penduduk Indonesia 2019 Mencapai 267 Juta Jiwa, https://databoks.katadata.co.id/datap ublish/2019/01/04/jumlah-

penduduk-indonesia-2019- mencapai267-juta-jiwa, diunduh hari Minggu tanggal 23 Juni 2019.

KBBI Daring, Dunia Maya, https://kbbi.kemdikbud.go.id/entri/d unia\%20maya, diunduh hari Minggu tanggal 23 Juni 2019.

Kitab Undang-undang Hukum Perdata (Burgelijk Wetboek) Edisi Revisi diterjemahkan oleh R Subekti dam R/ Tjitrosubibio. Jakarta : Pradmya Paramita. 2011

Kitab Undang-Undang Hukum Pidana (KUHP)

Kunjungi IG :

Kunjungi toko ini di Shopee! Ndfagunadi : https://shopee.co.id/ndfagunadi? $v=$ $675 \& s m t t=0.0 .3$

Mariam Darus Badrulzaman, Perjanjian Baku (Standard), Perkembangannya di Indonesia, Alumni, Bandung, 1980.

Peraturan Mahkamah Agung Nomor 2 Tahun 2015 Tentang Tata Cara Penyelesaian Gugatan Sederhana.

Peraturan Pemerintah Nomor 82 Tahun 2012 tentang Penyelenggaraan Sistem dan Transaksi Elektronik (PP PSTE). PP PSTE telah diperbarui menjadi Peraturan Pemerintah Nomor 71 Tahun 2019.Undang-Undang Republik Indonesia Nomor 17 Tahun 2007 Tentang Rencana Pembangunan Jangka Panjang Nasional Tahun 20052025.

Progresstech, Jenis-Jenis E-Commerce \& Contohnya, https://www.progresstech. co.id/blog/ jenis-e-commerce/,diunduh hari Minggu tanggal 23 Juni 2019.

R. Subekti, Hukum Perjanjian, Intermasa, Jakarta, 1976.
Sutan Remy Sjahdeini, Kebebasan Berkontrak dan Perlindungan Yang Seimbang bagi Para Pihak Dalam Perjanjian Kredit Bank Indonesia, Institut Bankir Indonesia, Jakarta, 1993.

Undang-Undang Dasar Negara Republik Indonesia Tahun 1945.

Undang-Undang Nomor 11 Tahun 2008 tentang Informasi dan Transaksi Elekronik sebagaimana telah diubah oleh Undang-Undang Nomor 19 Tahun 2016 tentang Perubahan Atas UndangUndang Nomor 11 Tahun 2008 tentang Informasi dan Transaksi Elektronik;

Undang-undang Perdagangan UndangUndang No 7 Tahun 2014

Undang-Undang Republik Indonesia Nomor 8 Tahun 1999 Tentang Perlindungan Konsumen.

Wahyunanda Kusuma Pertiwi, Facebook Jadi Medsos Paling Digemari Di Indonesia, https://tekno.kompas.com/read/2019/0 2/05/11080097/facebook-jadi-medsospaling-digemari-diindonesia, diunduh hari Minggu tanggal 23 Juni 2019. 